\title{
Vegetation dieback as a proxy for temperature within a wet pyroclastic density current: A novel experiment and observations from the 6th of August 2012 Tongariro eruption
}

\author{
Jackson T. Efford ${ }^{\text {a, }}$, Rebecca J. Bylsma ${ }^{\text {a }}$, Bruce D. Clarkson ${ }^{\text {a }}$, Adrian Pittari ${ }^{\text {b }}$, \\ Kate Mauriohooho ${ }^{\text {b }}$, Vicki G. Moon ${ }^{\text {b }}$ \\ a Environmental Research Institute, University of Waikato, Private Bag 3105, Hamilton 3240, New Zealand \\ b Department of Earth and Ocean Sciences, University of Waikato, Private Bag 3105, Hamilton 3240, New Zealand
}

\section{A R T I C L E I N F O}

\section{Article history:}

Received 7 July 2013

Accepted 15 May 2014

Available online $\mathrm{xxxx}$

\section{Keywords:}

Wet pyroclastic density current

Eruption

Temperature

Vegetation damage

Tongariro

Te Maari

\begin{abstract}
A B S T R A C T
The 6th of August 2012 eruption of Te Maari (Mt Tongariro, New Zealand) generated wet pyroclastic density currents (PDCs) which caused widespread dieback of vegetation (singed, brown foliage) in their path. An absence of significant charcoal formation suggests that PDC temperatures were mostly below $250{ }^{\circ} \mathrm{C}$. Textural evidence for liquid water being present in the matrices during emplacement (vesicles) suggests that temperatures were $<100{ }^{\circ} \mathrm{C}$. We determined a probable minimum PDC temperature using an experiment replicating the critical temperatures required to induce foliar browning in seven species affected by the eruption. In locations where all species exhibited browned foliage (or were defoliated), temperatures were probably $\geq 64{ }^{\circ} \mathrm{C}$ assuming a PDC duration of $60 \mathrm{~s}$. In the more distal areas, where only the most susceptible species were browned while others remained healthy and unaffected, temperatures were probably around $51-58{ }^{\circ} \mathrm{C}$. These results have relevance to volcanic hazard mitigation and risk assessment, especially on the popular Tongariro Alpine Crossing.
\end{abstract}

(c) 2014 Elsevier B.V. All rights reserved.

\section{Introduction}

Vegetation damage resulting from volcanic eruptions can provide important clues for constraining key eruption parameters including temperatures and dynamic pressures associated with pyroclastic density currents (PDCs). PDCs are amongst the most complex and dangerous volcanic phenomena, so determining emplacement temperature is important not only for understanding PDCs, but also for volcanic hazard mitigation and risk assessment (Sulpizio et al., 2008). Clarke and Voight (2000) have refined the use of tree damage to infer PDC dynamic pressures, and several different methods are available for determining the likely temperatures associated with PDCs. The presence of charcoal in a deposit for example, and subsequent petrographic or geochemical charcoal analysis, can indicate deposition temperatures in the range of approximately $250-1000{ }^{\circ} \mathrm{C}$ (e.g. Scott, 2000; Scott and Glasspool, 2005; Scott et al., 2008). Paleomagnetic analysis (thermal remnant magnetism) of lithic fragments or human artefacts is also useful for constraining PDC temperatures $>250{ }^{\circ} \mathrm{C}$ (e.g. McClelland and Druitt, 1989; Bardot, 2000; Zanella et al., 2007). Thermal deformation of

\footnotetext{
* Corresponding author. Tel.: + $6478592759,+64273134312$.

E-mail addresses: jackson.efford@waikatoregion.govt.nz (J.T. Efford), rbylsma@waikato.ac.nz (R.J. Bylsma), b.clarkson@waikato.ac.nz (B.D. Clarkson), apittari@waikato.ac.nz (A. Pittari), km179@waikato.ac.nz (K. Mauriohooho), vgmoon@waikato.ac.nz (V.G. Moon).
}

plastics and other materials exposed to PDCs has been used to constrain temperatures between 70 and $250{ }^{\circ} \mathrm{C}$ (e.g. Banks and Hoblitt, 1981; Voight and Davis, 2000; Alvarado and Soto, 2002), while microscopic examination of melted wax cuticles on tree needles has been used to constrain temperatures $>100{ }^{\circ} \mathrm{C}$ (Winner and Casadevall, 1981). There are fewer options available for constraining the temperatures of cooler PDCs that fail to produce any charcoal, alter lithics, or encounter other materials, other than to say that they were probably $<250{ }^{\circ} \mathrm{C}$. For these cooler PDCs, textural evidence for liquid water being present in the matrices during emplacement could be used to confirm temperatures below $<100{ }^{\circ} \mathrm{C}$ (McClelland et al., 2004), but this can often be ambiguous. Constraining PDC temperatures further below $100{ }^{\circ} \mathrm{C}$ may seem trivial, but has valuable applications for risk assessment, especially with regard to human survival. Air entrained by PDCs can be saturated with water vapour, and this acts to increase the amount of heat which is delivered to the human respiratory tract and skin compared with dryer heat. Inhaling dry, particle-free air at temperatures over $200{ }^{\circ} \mathrm{C}$ can be tolerated for short periods of time (Buettner, 1950; Purser, 1995), but the presence of steam or inhalable amounts of hot, fine ash, will reduce the temperature that can be tolerated to below $100{ }^{\circ} \mathrm{C}$. The human limit of tolerance for breathing saturated air is about $60{ }^{\circ} \mathrm{C}$, and inhaling saturated air and ash at temperatures between 50 and $100{ }^{\circ} \mathrm{C}$ is very hazardous, and can result in burns, acute bronchoconstriction, pulmonary injury and hypoxia (Baxter et al., 1998). 


\section{2012 Te Maari eruptions}

At 11.52 pm on the 6th of August 2012, the Central North Island volcano of Mt Tongariro (New Zealand) ended a 115 year period of quiescence with a sudden eruption from the upper Te Maari crater (Jolly et al., in this issue-a). The main eruption, which lasted about $20 \mathrm{~s}$ (Jolly et al. in this issue-a), produced a $7.8 \mathrm{~km}$-high ash plume (Crouch et al., in this issue), at least two widespread PDCs and debris jets (Jolly et al., in this issue-b). PDC deposits and ballistic blocks were dispersed as far as $2.2 \mathrm{~km}$ from the source, encompassing a section of the popular Tongariro Alpine Crossing tourist track (Breard et al., in this issue). Ash from the eruption plume travelled up to $200 \mathrm{~km}$ eastwards. A large landslide originating from the vent area also occurred $2.5 \mathrm{~min}$ prior to the eruption (Jolly et al., in this issue-b), emplacing a debris flow deposit of about $2 \mathrm{~km}$ down the flank of the mountain (Procter et al., in this issue). The total duration of the PDCs is estimated to have been around $60 \mathrm{~s}$, and the deposits generally consist of $<40 \mathrm{~cm}$-thick fine lapilli and coarse-medium ash (Lube et al., in this issue). Fournier and Jolly (in this issue), found evidence of a hot and/or humid plume and PDC in GPS signals at station VGOT located approximately $1 \mathrm{~km}$ due East of the vegetation dieback zone. They hypothesise that the plume originated from the earlier debris avalanche, followed immediately by the PDC. A second smaller eruption occurred on the 21st of November 2012, but failed to produce any significant PDCs.

Vegetation in the affected area has previously been mapped as tussock-shrubland, progressing through to gravelfield and stonefield, and then mossfield at higher elevations (Atkinson, 1981). The dominant tussock is Chionochloa rubra, scattered with sub-alpine shrubs including Dracophyllum recurvum, Podocarpus nivalis, Lepidothamnus laxifolius and various alpine herbs. Common shrub species include Phyllocladus alpinus, Hebe venustula, Coprosma pseudocuneata, Raukaua simplex and
Ozothamnus vauvilliersii. Pockets of taller scrub and forest dominated by $P$. alpinus grow locally within sheltered gullies, and frequently include Griselinia littoralis and Podocarpus cunninghamii in the canopy. We examined vegetation affected by the PDCs to the north-west of the vent from an ecological perspective in the months following the event (Fig. 1). Widespread dieback (characterised by plants having dead brown foliage) of tussock-shrubland and scrub vegetation clearly marked the extent of the PDCs across the landscape soon after the first eruption (Fig. 2). Uniform discoloration across both sides of leaf surfaces and an absence of any foliar pitting/pock-marking or abrasion suggests that it was likely to be heat, rather than acidity or dynamic pressure which inflicted the vegetation damage; the effected foliage was also widespread over trees and shrubs, including the more protected inner portions. Conversely, volcanic acidic damage on vegetation generally affects the outer portions of trees and shrubs (e.g. Nelson and Sewake, 2008). Tree blow-down and abrasion on vent-facing trunks were evident in locations proximal to the vent. In mid and distal locations, these effects were absent and the fine twig networks on most individual trees and shrubs were preserved. This indicates a significant decrease in dynamic pressure within the PDCs with increasing distance from the vent, and confirms that PDC dynamic pressures were not significant in the distal portions of the PDC which encountered vegetation. There were however obvious differences in species susceptibility to the PDCs. For example, at the distal ends of the PDCs it was possible to find a completely browned apparently dead $P$. alpinus tree alongside green and apparently unaffected $P$. nivalis sub-shrubs (Fig. 3 ), while in the mid portions of the PDC, both of these species exhibited complete foliar browning. Ash plastering on trees and abundant vesiculation of the deposit plaster indicate the presence of liquid water as opposed to water vapour during emplacement and this suggests that emplacement temperatures were probably below $100{ }^{\circ} \mathrm{C}$ (Lube et al., in this issue;

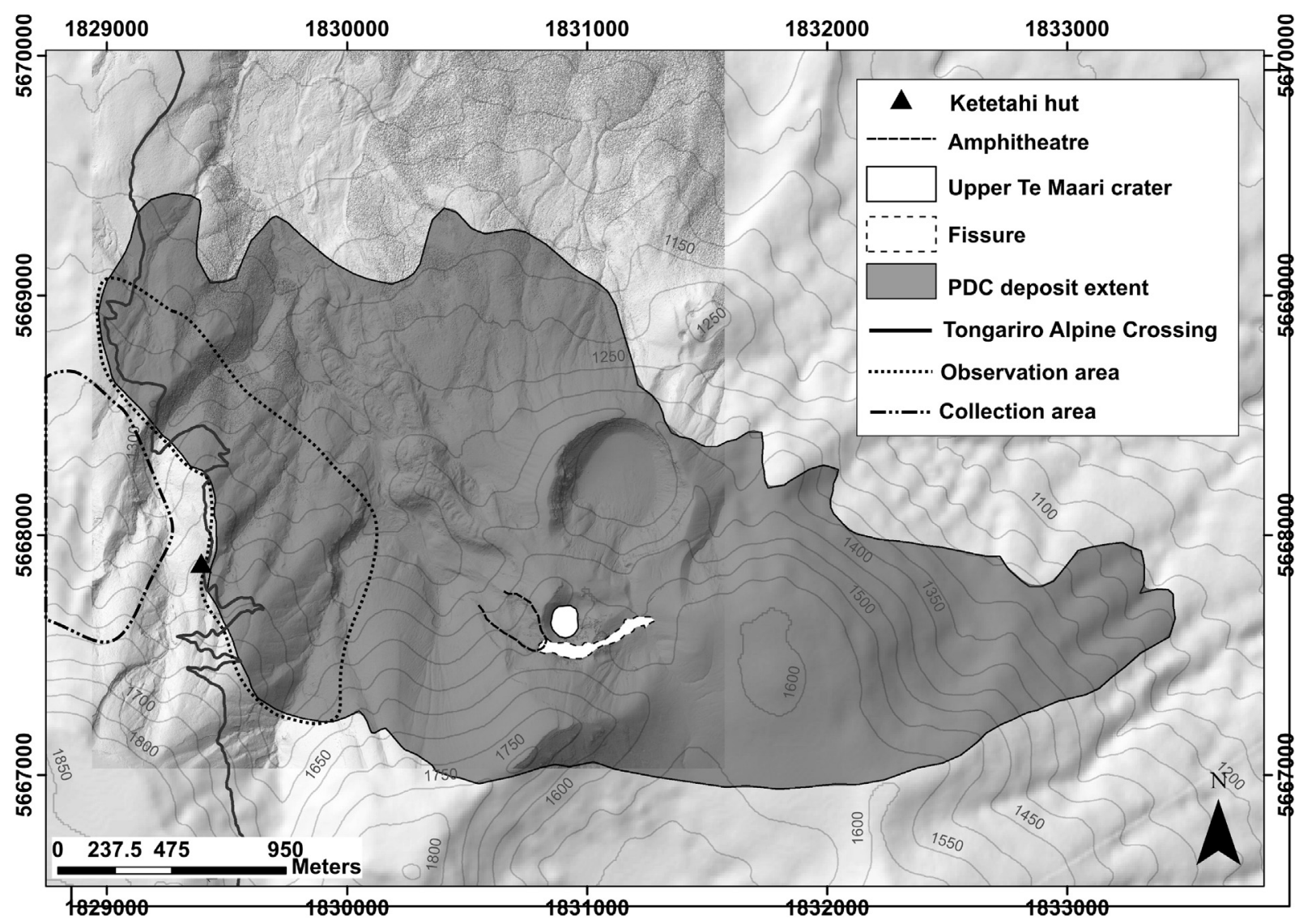

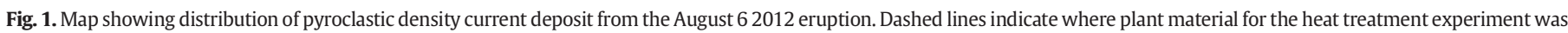
collected and where browned vegetation was examined (figure modified from Lube et al. in this issue). 

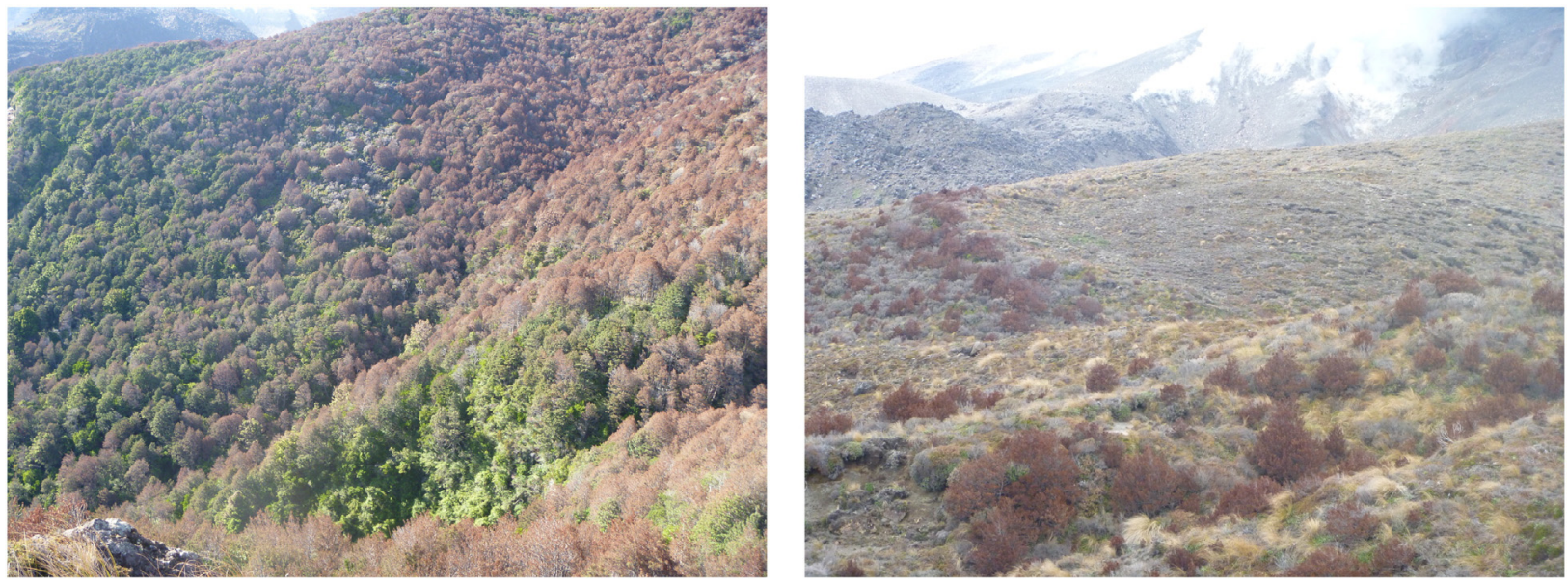

Fig. 2. Vegetation dieback in scrub (left) and tussock-shrubland (right) as a result of PDCs on Mt Tongariro.

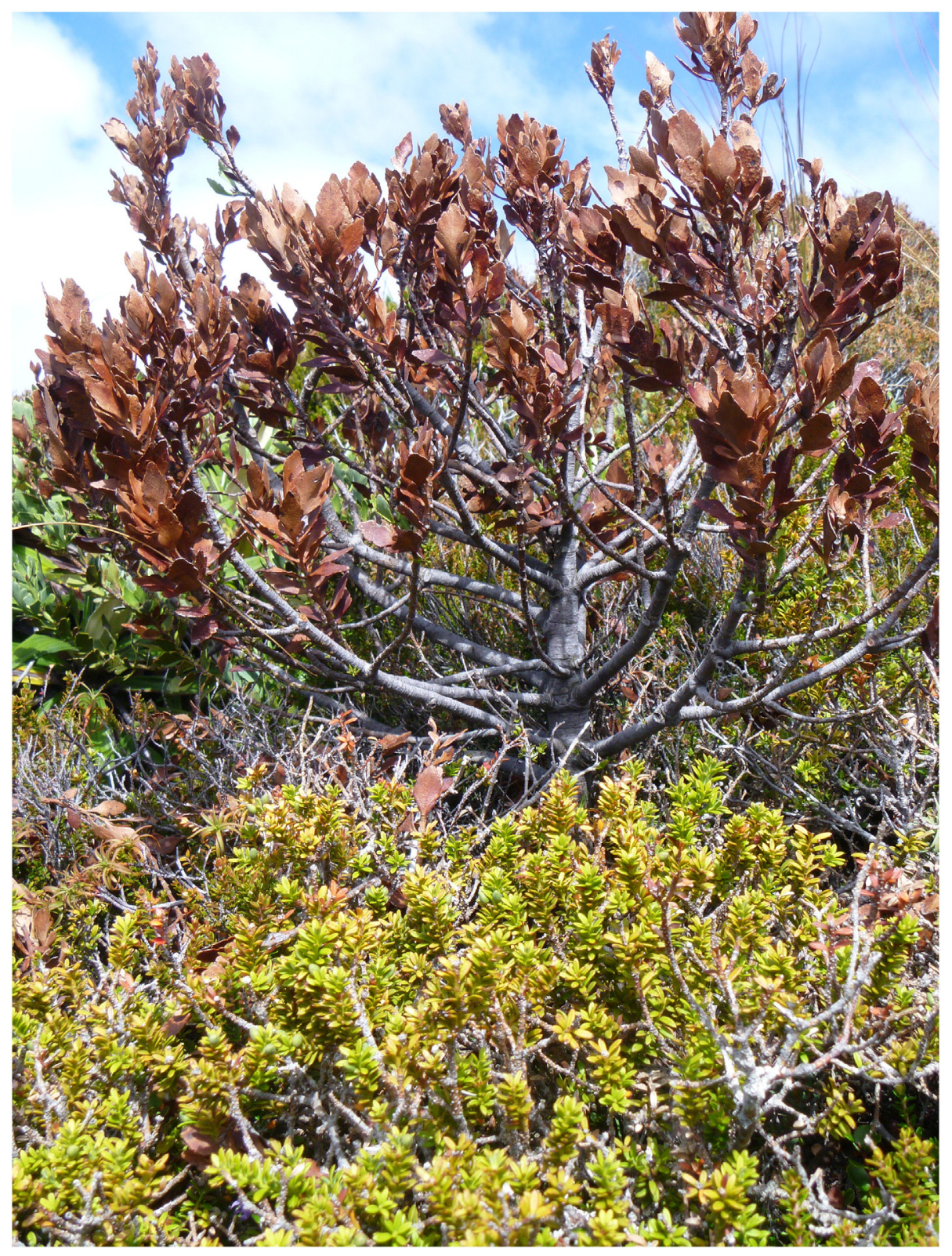

Fig. 3. Browned Phyllocladus above a green unaffected Podocarpus at the distal end of the PDC. 
tuffs of Lorenz, 1974; Fisher and Schmincke, 1984). However, rare sites with superficially charred bark at the upstream side of tree stems where found, and these may suggest localised hot particles within the PDC $>250{ }^{\circ} \mathrm{C}$ (Lube et al., this volume). We suggest effected vegetation results predominantly from the PDC (Lube et al., in this issue) and not the preceding gas charged debris avalanche plume (Fournier et al., in this issue), because the spatial extent of the PDC deposits and vegetation dieback are similar (Fig. 1). We seek to constrain PDC temperature using a novel experiment to replicate temperatures required to induce vegetation browning in different species with the goal of providing a tool to enable volcanologists and land managers to better mitigate PDC hazards.

\section{Methods}

Branchlets with green unaffected leaves (strictly cladodes rather than leaves in Phyllocladus) were collected from seven species growing just outside the path of the PDC on Mt Tongariro (Fig. 1); P. alpinus (Phyllocladaceae), P. nivalis (Podocarpaceae), $H$. venustula (Plantaginaceae), C. pseudocuneata (Rubiaceae), D. recurvum (Ericaceae), G. littoralis (Griseliniaceae), and O. vauvilliersii (Asteraceae) - hereafter referred to by genus only. Sampling targeted multiple individuals from each species and included a range of leaf sizes and ages. Leaves were immersed in a chilled water bath of $2{ }^{\circ} \mathrm{C}$ for $3 \mathrm{~h}$ to acclimate tissues to the approximate ambient air temperature at the time of the eruption (based on measurements from adjoining Mt Ruapehu, NIWA Climate Database - http://cliflo.niwa.co.nz). For the first heat treatment simulating the PDC, five leaves of each species were plunged into a second water bath heated to a constant $40{ }^{\circ} \mathrm{C}$ for a period of $60 \mathrm{~s}$, before being removed. To act as a control, several leaves of each species were removed from the chilled water bath at the same time and not exposed to the heated water. This process was then repeated 29 times with the temperature in the hot water bath being increased successively in $1{ }^{\circ} \mathrm{C}$ increments. Following the heat treatments, leaves were rested for $48 \mathrm{~h}$ to allow time for the full effects (i.e., browning) to become apparent. After this rest period all control leaves still remained green and unaffected. To determine the effect of leaf exposure time to heat, a second similar experiment was conducted with only two of the species (Phyllocladus and Podocarpus). The procedure was identical to the previous experiment, except batches of leaves were immersed in the hot water bath for durations of $30 \mathrm{~s}$ and $120 \mathrm{~s}$. The results of both experiments were interpreted as the proportion of leaves browned in each species at each temperature treatment. ANOVA and post-hoc Fisher LSD tests were used to detect significant differences between the browning of Phyllocladus and Podocarpus following the exposure treatments $(30,60,120 \mathrm{~s})$.

\section{Results}

The experiment simulating the effect of PDC heat on vegetation was successful at determining the temperatures required to induce leaf browning in the species tested (Figs. 4 and 5). Most species displayed browning over a range of temperatures, therefore the critical browning temperature (hereafter $\mathrm{CBT}$ ) can be considered as the range from the minimum temperature at which at least one leaf from the sample displayed browning, to the minimum temperature where $100 \%$ of the leaves were browned. Based on a leaf exposure time to heat of $60 \mathrm{~s}$, Phyllocladus was the most susceptible species of those tested, with a CBT of $51-58{ }^{\circ} \mathrm{C}$. Podocarpus and Coprosma were the most resilient species, with CBTs of $58-64{ }^{\circ} \mathrm{C}$ and $58-59{ }^{\circ} \mathrm{C}$, respectively. The remaining species CBTs were distributed amongst these extremes. Shortening heat exposure time to $30 \mathrm{~s}$ significantly $(P<0.05)$ raised the $\mathrm{CBT}$ in Phyllocladus foliage (CBT of $58-62{ }^{\circ} \mathrm{C}$ ), but not Podocarpus (CBT of $59-63{ }^{\circ} \mathrm{C}$ ). Increasing heat exposure time to $120 \mathrm{~s}$ did not significantly change the CBT range in Phyllocladus (CBT of $52-58{ }^{\circ} \mathrm{C}$ ) or Podocarpus (CBT of $57-61{ }^{\circ} \mathrm{C}$ ).
Phyllocladus alpinus

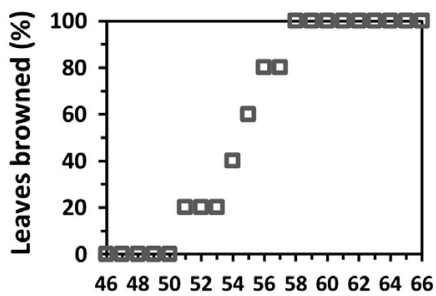

Coprosma pseudocuneata

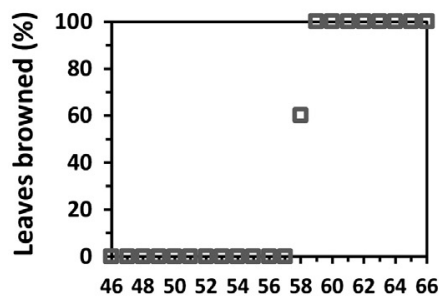

Dracophyllum recurvum

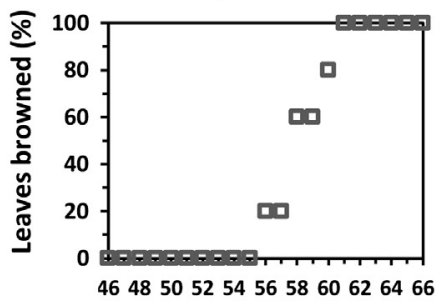

Ozothamnus vauvilliersii

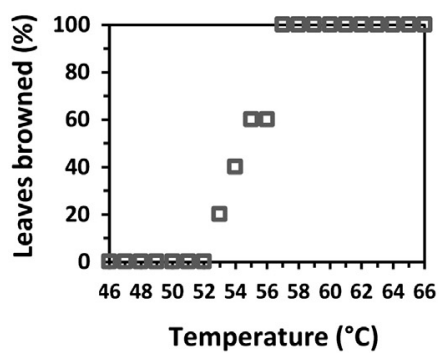

Fig. 4. Temperatures required to induce foliar browning in seven species exposed to water bath heat for $60 \mathrm{~s}$

\section{Discussion}

The results of our leaf browning experiment provide an approximation of the minimum PDC temperature from the 6th of August 2012 Te Maari eruption. At the mid portions of the PDC, where all species exhibited browned foliage in the field, the minimum temperature was probably $\geq 64{ }^{\circ} \mathrm{C}$. This is determined from the temperature required to brown all foliage of Podocarpus (the most resilient species tested) within $60 \mathrm{~s}$ of heat exposure. Had the duration of the PDC been shorter (30 s) or longer (120 s) than this, our results suggest that this temperature estimate would not change by more than a few degrees. A PDC temperature range of approximately $64-100{ }^{\circ} \mathrm{C}$ can therefore be confirmed in the field where 1 ) all vegetation was browned and, 2) where deposit textures indicate a wet PDC. Proximal to the vent, where deposit textures are not indicative of a wet surge, the maximum temperature is more difficult to constrain; the very rare finds of surficial charring on the upstream.

Side of tree stems (Lube et al., in this issue) means we cannot rule out localised PDC particle temperatures $>250{ }^{\circ} \mathrm{C}$ in proximal locations (i.e. minimum temperature required to produce charcoal; Scott, 

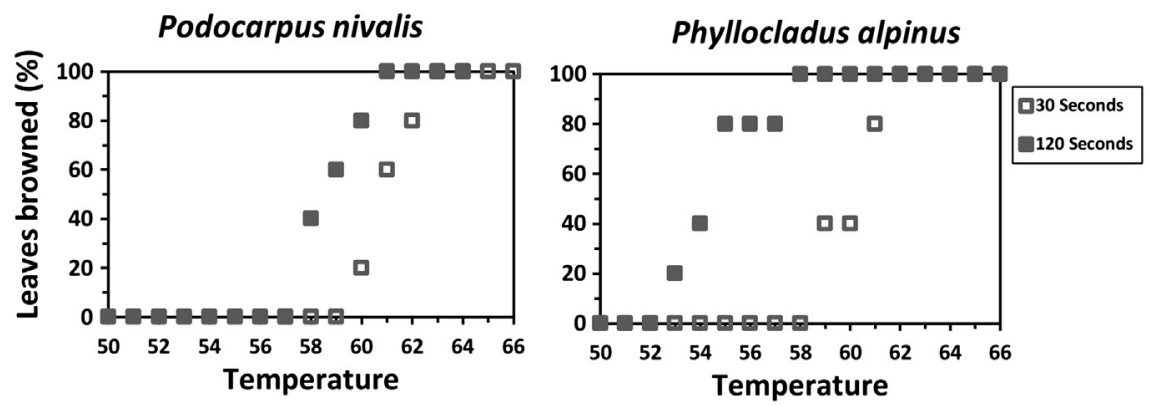

Fig. 5. Temperatures required to induce foliar browning in two species exposed to water bath heat for 30 and $120 \mathrm{~s}$.

2000). In more distal locations, where only the most susceptible species (e.g. Phyllocladus) were browned, while others (e.g. Podocarpus) remained unaffected, PDC temperature could be estimated as approximately $51-58{ }^{\circ} \mathrm{C}$.

A combination of differences in both species height and susceptibility to heat likely explains the variable vegetation dieback observed across the PDC deposit as plants which are emergent (taller than surrounding vegetation) would be more directly exposed to the heat and effects of a PDC. For example, Phyllocladus typically grows emergently, which, coupled with its vulnerability to heat damage, explains the extent of its dieback and supports the likelihood that it was probably heat as opposed to acid which caused the damage. Other evidence for this includes the nature of the vegetation recovery; within the three months that followed the eruption vegetation recovery had already begun, with some entirely browned plants re-sprouting new foliage. Re-sprouts emerged from the plants' thicker central stems as opposed to thin twigs on the extremities, and this also indicates that heat rather than acid caused the vegetation die-back (Swanson et al., 2013). However, because the chemical composition of the PDCs is known to have been complex (Cronin et al., in this issue) we cannot completely rule out the compounding impacts of acidity and heat on the vegetation.

Particle size and concentration within the PDCs were strongly vertically and laterally stratified (Lube et al., in this issue) and this could also implicate the damage to vegetation. Initial jets were particle-rich and produced a fine-ash poor breccia up to $1 \mathrm{~km}$ from the vent. As these jets collapsed, a turbulent and highly stratified surge produced a finecoarse ash layer and above this, fine-medium ash was deposited up to c. $2.2 \mathrm{~km}$ by gentle turbulent dilute phoenix clouds (Lube et al., in this issue). Due to thermal mass and dynamics, particle-rich PDCs will have more rapid and efficient heat transfer to plant foliage; we could therefore expect basal plant foliage to be more susceptible to heat damage, as the basal layers of the PDCs were more particle-rich than the upper layers. However, despite strong stratification within the PDCs (Lube at al., in this issue), we did not observe vertical patterns of leaf browning on plants. At the mid and distal portions of the PDC deposits, where we conducted the majority of our field work, particle concentrations within the PDCs may have been so low that stratification had a negligible effect on leaf browning. However, closer to the source, plants also displayed uniform vertical browning. Here, the short stature of the tussock-shrubland vegetation could have rendered the majority of plants susceptible to the particle-rich basal flows; in the few places where the PDCs entered taller vegetation, ash spatter persisted on trunks up to c. $1700 \mathrm{~cm}$ above the ground, well above the height of most tussock-shrubland vegetation. In proximal locations, it is likely that the temperature of the PDCs were well above the browning thresholds of all species. Uniform lateral browning of vegetation may also result from heat being transported in the gas/water phase of the PDCs, typical of steam-driven, non-juvenile dominated PDCs (Lube et al. in this issue), as opposed to in the suspended particles. Accordingly, vertical variation in particle concentration would have minimal effect on plant browning.
Ecological and physiological studies have been published on the lethal upper-temperatures for trees (though none for New Zealand species), all in relation to tree survival during wild fire (Hare, 1961). The external temperature which may be lethal for a given plant tissue is complex and depends on many factors including the initial temperature of the tissue, the insulating qualities of dead tissue such as bark which separates the living cells from the heat source, and the duration of exposure (Hare, 1961). An obvious limitation of our experiment is the use of a water bath to transfer heat to the foliage, as it is not directly comparable to heat from a PDC, and could be assumed to have different physiological implications for the plant than a dryer heat. Although the moisture content within the PDCs from the Te Maari eruption are unknown, Hare (1961) suggests that whether heat is delivered to foliage experimentally by water or as a dry heat (e.g. an oven), the critical temperature for the plant remains largely unchanged, thus providing some validation for our method. We also conducted crude preliminary trials using a steam gun to replicate PDC heat and moisture on foliage, and this too successfully induced browning at similar temperatures (Mauriohooho et al., 2013). Other published studies on upper lethal temperatures for plants (mostly conifers) are analogous with the foliage browning temperatures deduced from our experiment; e.g. 30 s at $63{ }^{\circ} \mathrm{C}$ (Nelson, 1952); $1 \mathrm{~min}$ at $60{ }^{\circ} \mathrm{C}$ (Bates and Roeser, 1924); 1 min at $66{ }^{\circ} \mathrm{C}$ (Lorenz, 1939); 2 min at $54{ }^{\circ} \mathrm{C}$; and 5 min at $51{ }^{\circ} \mathrm{C}$ (Baker, 1929). Other PDCs from volcanoes elsewhere in the world are also reported to have singed vegetation without producing significant charcoal, including Mt Katmai, United States (Griggs, 1915), Mt St Helens, United States (Lipman and Mullineaux, 1981), Mt Shiveluch, Russia (Grishin, 2009), and Chaiten, Chile (Major et al., 2013; Swanson et al., 2013).

Our mid $\left(>64{ }^{\circ} \mathrm{C}\right)$ and distal $\left(51-58{ }^{\circ} \mathrm{C}\right)$ PDC temperature estimates for the 6th of August 2012 Te Maari eruption could have potentially resulted in severe injuries (e.g. burns and respiratory damage) or even fatalities (Baxter et al., 1998) if visitors on the mountain had been exposed, and this has significant implications to volcanic hazard management of the Tongariro Alpine Crossing. We have demonstrated the use of a novel method to determine likely minimum temperatures associated with cool PDCs which encounter and damage vegetation by heat but fail to generate any charcoal. Others may apply or refine this technique for interpreting future eruptions.

\section{Acknowledgements}

We give our thanks to the New Zealand Department of Conservation (especially Dr Harry Keys and Bubs Smith) for granting us access into Tongariro National Park and providing logistical support, including helicopter flights into the eruption area. Eric Breard kindly helped in the field with interpreting the eruption and PDC deposits. This project was supported by funding from the Environmental Research Institute, University of Waikato. We also thank Gert Lube and an anonymous reviewer for providing constructive comments on an earlier draft of the manuscript. 


\section{References}

Alvarado, G.E., Soto, J.G., 2002. Pyroclastic flow generated by crater-wall collapse and outpouring of the lava pool of Arenal Volcano, Costa Rica. Bull. Volcanol. 63, 557-568.

Atkinson, I.A.E., 1981. Vegetation map of Tongariro National Park, North Island, New Zealand (Scale 1:50 000). New Zealand Department of Scientific and Industrial Research, Wellington.

Baker, F.S., 1929. Effect of excessively high temperatures on coniferous reproduction. J. For. 27, 949-975.

Banks, N.G., Hoblitt, R.P. 1981. Summary of temperature studies of 1980 deposits. In: Lipman, P.W., Mullineaux, D.R. (Eds.), The 1980 Eruptions of Mount St. Helens, Washington. United States Geological Survey Professional Paper, 1250, pp. 295-313.

Bardot, L., 2000. Emplacement temperature determinations of proximal pyroclastic deposits on Santorini, Greece, and their implications. Bull. Volcanol. 61, 450-467.

Bates, C.G., Roeser, J. Jr, 1924. Relative resistance of tree seedlings to excessive heat. United States Department of Agriculture Bulletin, 1263, (16 pp.).

Baxter, P.J., Neri, A., Todesco, M., 1998. Physical modelling and human survival in pyroclastic flows. Nat. Hazards 17, 163-176.

Buettner, K., 1950. Effects of extreme heat in man. J. Am. Med. Assoc. 144, 732-738.

Clarke, A.B., Voight, B., 2000. Pyroclastic current dynamic pressure from aerodynamics of tree or pole blow-down. J. Volcanol. Geotherm. Res. 100, 395-412.

Cronin, S.J., Stewart, C., Zernack, A.V., Brenna, M., Procter, J.N., Pardo, N., Christenson, B., Wilson, T.M., Stewart, R.B., Irwin, M., 2014. Volcanic ash leachate compositions and assessment of health and agricultural hazards from 2012 hydrothermal eruptions, Tongariro, New Zealand. J. Volcanol. Geotherm. Res. (in this issue).

Crouch, J., Pardo, N., Miller, C.A., 2014. Dual polarisation C-band weather radar imagery of the 6 August 2012 Te Maari Eruption, Mount Tongariro, New Zealand. J. Volcanol. Geotherm. Res. (in this issue).

Fisher, R.V., Schmincke, H.U., 1984. Pyroclastic Rocks. Springer-Verlag, Berlin, New York, (472 pp.).

Fournier, N., Jolly, A.D., 2014. Detecting complex eruption sequence and directionality from high-rate geodetic observations: the August 6, 2012 Te Maari eruption, Tongariro, New Zealand. J. Volcanol. Geotherm. Res. (in this issue).

Griggs, R.F., 1915. The effect of the eruption of Katmai on land vegetation. Bull. Am. Geogr. Soc. 47, 193-203.

Grishin, S.Y., 2009. Forest die-off under the impact of burning pyroclastic surge on the Shiveluch volcano (Kamchatka, 2005). Russ. J. Ecol. 40, 146-148.

Hare, R.C., 1961. Heat effects on living plants. United States Forest Service Southern Forest Experiment Station. Occas. Pap. 183 (32 pp.).

Jolly, A.D., Jousset, P., Lyons, J.J., Carniel, R., Fournier, N., Fry, B., Miller, C., 2014a. Seismoacoustic evidence for an avalanche driven phreatic eruption through a beheaded hydrothermal system: an example from the 2012 Tongariro eruption. J. Volcanol. Geotherm. Res. (in this issue).

Jolly, A.D., Lokmer, I., Kennedy, B., Keys, H., Proctor, J., Lyons, J.J., Jolly, G.E., 2014b. Active seismic sources as a proxy for seismic surface processes: an example from the 2012 Tongariro volcanic eruptions, New Zealand. J. Volcanol. Geotherm. Res. (in this issue).

Lipman, P.W., Mullineaux, D.R. (Eds.), 1981. The 1980 Eruptions of Mount St. Helens, Washington. United States Geological Survey Professional Paper, 1250 (844 pp.).
Lorenz, R.W., 1939. High temperature tolerance of forest trees. University of Minnesota Agricultural Experiment Station. Tech. Bull. 141 (25 pp.).

Lorenz, V., 1974. Vesiculated tuffs and associated features. Sedimentology 21, 273-291.

Major, J.J., Pierson, T.C., Hoblitt, R.P., Moreno, H., 2013. Pyroclastic density currents associated with the 2008-2009 eruption of Chaitén Volcano (Chile): forest disturbances, deposits, and dynamics. Andean Geol. 40, 324-358.

Mauriohooho, K., Moon, V.G., Efford, J.T., Clarkson, B.D., Pittari, A., 2013. The effect of pyroclastic surges from the August 6th 2012 Te Maari eruption on vegetation, and associated hazard implications. Abstract, Te Maari Day, 22 March, 2013, Turangi New Zealand. GNS Science Miscellaneous Series,.

Lube, G., Breard, E.C.P., Cronin, S.J., Procter, J.N., Brenna, M., Moebis, A., Pardo, N., Stewart, R.B., Jolly, A., Fournier, N., 2014. Dynamics of surges generated by hydrothermal blasts during the 6 August 2012 Te Maari eruption, Mt. Tongariro, New Zealand, J. Volcanol. Geotherm. Res, (in this issue).

McClelland, E.A., Druitt, T.H., 1989. Palaeomagnetic estimates of emplacement temperatures of pyroclastic deposits on Santorini, Greece. Bull. Volcanol. 51, 16-27.

McClelland, E., Wilson, C.J.N., Bardot, L., 2004. Palaeotemperature determinations for the 1.8-ka Taupo ignimbrite, New Zealand, and implications for the emplacement history of a high-velocity pyroclastic flow. Bull. Volcanol. 66, 492-513.

Nelson, R.M., 1952. Observations on heat tolerance of southern pine needles. United States Forest Service Southern Forest Experiment Station, Paper, 14, (66 pp.).

Nelson, S., Sewake, K., 2008. Volcanic emissions injury to plant foliage. Plant Dis. 47, 1-11.

Procter, J., Cronin, S., Zernack, A., Lube, G., Stewart, B., Nemeth, K., Keys, H., 2014. Debris flow evolution and activation of an explosive hydrothermal system; Te Maari, Tongariro, New Zealand. J. Volcanol. Geotherm. Res. (in this issue).

Purser, D.A., 1995. Section 2 in SFPE Handbook of Fire Protection Engineering, 2nd edn. National Fire Protection Association, Quincy MA, pp. 85-146.

Scott, A.C., 2000. The pre-quaternary history of fire. Palaeogeogr. Palaeoclimatol. Palaeoecol. 164, 297-345.

Scott, A.C., Glasspool, I.J., 2005. Charcoal reflectance as a proxy for the emplacement temperature of pyroclastic flow deposits. Geology 33 (7), 589-592.

Scott, A.C., Sparks, R.S.J., Bull, I.D., Knicker, H., Evershed, R.P., 2008. Temperature proxy data and their significance for the understanding of pyroclastic density currents. Geology 36, 143-146.

Sulpizio, R., Zanella, E., Macías, J.L., 2008. Deposition temperature of some PDC deposits from the 1982 eruption of El Chichón volcano (Chiapas, Mexico) inferred from rock-magnetic data. J. Volcanol. Geotherm. Res. 175, 494-500.

Swanson, F.J., Jones, J.A., Crisafulli, C.M., Lara, A., 2013. Effects of volcanic and hydrologic processes on forest vegetation: Chaitén Volcano, Chile. Andean Geol. 40, 359-391.

Voight, B., Davis, M.J., 2000. Emplacement temperatures of the November 22, 1994 Nuees artdetes deposites. J. Volcanol. Geotherm. Res. 100, 371-377.

Winner, W.E. Casadevall, T.J., 1981. Fir leaves as thermometers during the May 18 eruption. In: Lipman, P.W., Mullineaux, D.R. (Eds.), The 1980 Eruptions of Mount St. Helens, Washington. United States Geological Survey Professional Paper, 1250 pp. 315-320.

Zanella, E., Gurioli, L., Pareschi, M.T., Lanza, R., 2007. Influences of urban fabric on pyroclastic density currents at Pompeii (Italy): 2. Temperature of the deposits and hazard implications. J. Geophys. Res. 112. http://dx.doi.org/10.1029/2006JB004775. 